\title{
Pengembangan Trainer Aplikasi Multi-Sensors (TAMS) Berbasis Arduino dan Raspberry Pi
}

\author{
Muhammad Yusro', Mufti Ma'sum², Marie Muhamad ${ }^{3}$ dan Ariep Jaenul ${ }^{4}$ \\ 1,2,3 Universitas Negeri Jakarta, Indonesia \\ ${ }^{4}$ Jakarta Global University, Indonesia
}

\begin{abstract}
At the higher education level in the field of engineering, the development and utilization of educational media for practical learning is needed to ensure that students have technical skills and not just theory. The purpose of this study is to develop practical learning media for the transducer sensor subject and industrial instrumentation in the Multi-Sensor Application Trainer (TAMS). The trainer is based on current developments in transducer sensor technology and control systems. The research method used is research and development (R \& D) using a media development model with ADDIE (analysis, design, development, implementation, and evaluation). Developing this trainer includes making hardware (hardware) and software (software). This trainer has various sensors, outputs, and a control module in the Arduino Mega2560 and is supported by the Raspberry Pi. This trainer is equipped with a practicum module that contains 15 (fifteen) practicum that will be used by students. The results of the validity test by material experts obtained an average percentage of the assessment score of $85.25 \%$ which means that it is valid and very feasible to use. The results of the validity test by media experts obtained an average percentage of the assessment score of $78.04 \%$, which means that it is valid and very feasible to use. The results of the student's assessment of the use of trainers are $90 \%$, so it can be concluded that the TAMS is very suitable for use. Qualitatively, students considered that the TAMS could function well and be easy to use.
\end{abstract}

\section{ABSTRAK}

Pada jenjang pendidikan tinggi bidang keteknikan, pengembangan dan pemanfaatan media pendidikan untuk pembelajaran praktik diperlukan untuk memastikan bahwa mahasiswa memiliki keterampilan teknis dan tidak hanya teori. Tujuan penelitian ini adalah untuk mengembangkan media pembelajaran praktik mata kuliah sensor transduser dan instrumentasi industri berupa Trainer Aplikasi Multi-Sensor (TAMS). Trainer dibuat berdasarkan perkembangan teknologi sensor transduser dan sistem kendali saat ini. Metode penelitian yang digunakan adalah research and development (R \& D) menggunakan model pengembangan media dengan ADDIE (analysis, design, development, implementation and evaluation). Pembuatan trainer ini meliputi pembuatan perangkat keras (hardware) dan perangkat lunak (software). Trainer ini memiliki berbagai sensor, output serta modul pengendali berupa Arduino Mega2560 dan didukung oleh Raspberry Pi. Trainer ini dilengkapi dengan modul praktikum yang berisi 15 (lima belas) judul praktikum yang akan digunakan pada trainer. Hasil uji validitas oleh ahli materi memperoleh persentase rata-rata skor penilaian sebesar $85,25 \%$ yang berarti valid dan sangat layak digunakan. Hasil uji validitas oleh ahli media memperoleh persentase rata-rata skor penilaian sebesar $78,04 \%$ yang berarti valid dan sangat layak digunakan. Hasil penilaian mahasiswa terhadap penggunaan trainer adalah sebesar 90\% sehingga dapat disimpulkan bahwa trainer TAMS sangat layak digunakan. Secara kualitatif mahasiswa menilai bahwa trainer TAMS dapat berfungsi dengan baik dan mudah untuk digunakan.

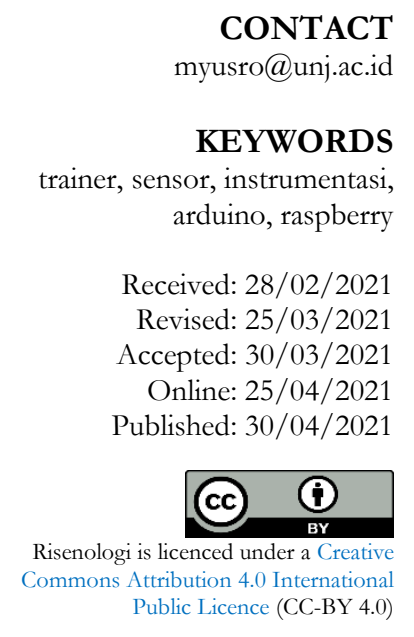

CONTACT
myusro@unj.ac.id

KEYWORDS

arduino, raspberry

Received: $28 / 02 / 2021$

Revised: $25 / 03 / 2021$

ccepted: $30 / 03 / 2021$

Online: $25 / 04 / 2021$

Published: 30/04/2021

Public Licence (CC-BY 4.0)

\section{PENDAHULUAN}

Teknologi banyak memberikan manfaat di berbagai bidang kehidupan masyarakat seperti pendidikan, kesehatan, kuliner, pertanian, dan lain sebagainya. Hampir setiap manusia menggunakan teknologi untuk menyelesaikan permasalahan yang dihadapinya. Seiring berkembangnya waktu, perkembangan teknologi juga harus diimbangi dengan perkembangan pada Sumber Daya Manusia (SDM). Teknologi menyebabkan perubahan struktural mendasar dalam sistem pendidikan dan dapat meningkatkan produktivitas yang signifikan. Teknologi digunakan untuk mendukung pengajaran dan pembelajaran dengan berbagai kelebihan yang dimiliki yakni teknologi dapat digunakan di ruang kelas dengan alat belajar digital seperti komputer dan perangkat genggam; memperluas jangkauan penawaran kursus/pendidikan, pengalaman, dan materi pembelajaran; mendukung 
pembelajaran 24 jam sehari 7 hari seminggu; membangun keterampilan abad ke-21; meningkatkan keterlibatan dan motivasi siswa; dan mempercepat pembelajaran (U.S. Departement of Education, 2019).

Peningkatan teknologi pembelajaran (Teknologi Enhanced Learning/TEL) telah menjadi fitur umum yang digunakan di pendidikan tinggi (kampus). Sebuah studi dilakukan untuk menilai dampak keterlibatan emosional, kognitif, dan perilaku pemanfaatan TEL terhadap nilai siswa. Hasil studi menunjukkan bahwa penggunaan kelompok media sosial merupakan prediktor yang signifikan mempengaruh nilai siswa dibandingkan pembelajaran menggunakan slide/rekaman ceramah, membaca konten tambahan atau menggunakan blog (Dunn \& Kennedy, 2019). Pembelajaran menggunakan gamifikasi juga banyak dikembangkan. Sebuah studi menunjukkan dampak teknologi informasi dan komunikasi (TIK) dalam pembelajaran berupa gamifikasi dapat meningkatkan penguasaan pembelajaran peserta didik secara signifikan, pembelajaran berbantuan teknologi juga meminimalkan gangguan pada peserta didik dan meningkatkan kurva belajar (Kayimbaşioğlu et al., 2016). Pada suatu studi systematik review memaparkan beragam teknologi yang sedang digunakan dan teknologi paling populer adalah permainan (games) (18,4\%), alat Web 2.0 (14,8\%), dan pembelajaran seluler (mobile learning) (14,8\%). Teknologi lain yang berkaitan dengan instruksi digital, sistem manajemen pembelajaran online, animasi dan simulasi, sistem umpan balik, Massive Open Online Courses (MOOCs), sistem respons siswa, teknologi pemrograman, angmented reality, robotika, dan e-book (Lai \& Bower, 2019).

Penelitian tentang pengembangan media pembelajaran praktik (trainer) bidang keteknikan telah dilakukan oleh para peneliti dengan tujuan meningkatkan pemahaman dan keterampilan siswa. Sebuah studi yang dilakukan oleh Charles Hacker dari Griffith University, Gold Coast, Australia (Hacker, 2009) menghasilkan suatu media pembelajaran teknik digital yang berbiaya murah dan dapat digunakan para siswa belajar untuk mendalami pelajaran rangkaian digital. Tujuan utamanya adalah merancang perangkat yang murah dan mudah digunakan oleh siswa, sehingga mereka dapat melakukan eksperimen digital di rumah. Hal yang sama terkait dengan pengembangan media pembelajaran teknik juga dikembangkan oleh Sahat (Sahat Siagian, 2014) yang bertujuan untuk menghasilkan modul dan trainer tentang penguasaan kompetensi dasar elektronik mahasiswa. Penelitian ini digunakan pula untuk mengetahui efektifitas modul dan trainer dalam meningkatkan hasil pengajaran atau menguasai kompetensi. Elfizon dkk (Elfizon et al., 2017) juga membuat penelitian tentang pengembangan media trainer elektronika dalam pembelajaran teknik elektronika. Penelitian ini bertujuan mengembangkan media trainer elektronika yang valid, praktis dan efektif dalam pembelajaran teknik elektronika. Pengembangan modul training logika digital untuk eksperimen laboratorium siswa dilakukan oleh L. A. Ajao dkk (Ajao et al., 2017). Modul trainer logika digital ini dirancang untuk menyederhanakan masalah siswa dalam mempelajari elektronika dasar, sistem logika digital, dan arsitektur komputer. Fitur sistem trainer ini memberikan keuntungan pada pembelajaran praktik guna meningkatkan pengetahuan teoritis siswa serta membantu siswa untuk memvalidasi bukti logika dan desain sirkuit terkait dengan gerbang logika dasar, sirkuit logika kombinasional dan rangkaian logika berurutan.

Berdasarkan beberapa penelitian yang telah diuraikan, nampak jelas pemanfaatan teknologi untuk pendidikan khususnya dalam pengembangan media pembelajaran, baik pembelajaran teori maupun praktik dari semua level/jenjang pendidikan, mulai dari pendidikan dasar (sekolah) hingga pendidikan tinggi (Yusro, 2017). Dalam konteks pendidikan tinggi keteknikan, pemanfaatan media pendidikan untuk pembelajaran praktik diperlukan untuk memastikan bahwa mahasiswa memiliki keterampilan teknis dalam mengoperasikan suatu pekerjaan tertentu, misalnya kemampuan menggunakan alat ukur, mengkalibrasi alat ukur sampai dengan melakukan pengukuran pada objek kerja menggunakan alat ukur. Universitas Negeri Jakarta sebagai salah satu institusi pendidikan tinggi memiliki berbagai beberapa program studi keteknikan, di antaranya yakni Program Studi Pendidikan Teknik Elektronika (Prodi PTE). Program Studi ini bertujuan untuk menghasilkan sarjana pendidikan teknik yang menguasai teori dan aplikasi ilmu teknik elektronika di dunia pendidikan maupun industri. Lulusan pun dituntut untuk menguasai materi dan praktikum di bidang teknik elektronika.

Dari proses pengamatan yang dilakukan peneliti, proses perkuliahan di Prodi PTE ini sudah berlangsung baik, namun pada saat praktikum masih belum optimal karena minimnya peralatan praktikum (trainer) yang sesuai dengan kompetensi keahlian mahasiswa. Saat ini, trainer yang dimiliki oleh program studi merupakan trainer produk lama yang berusia lebih dari 15 tahun yang sebagian besarnya telah rusak dan sulit untuk diperbaiki karena sulitnya mendapatkan suku cadang (spare part). Kondisi kepemilikan peralatan praktikum ini agak memprihatinkan jika dibandingkan dengan peralatan praktikum yang dimiliki oleh beberapa Sekolah Menengah Kejuruan (SMK) yang sudah baik dan lengkap. Keterbatasan jumlah trainer inilah yang menyebabkan banyak kegiatan praktikum terkendala, karena idealnya setiap mahasiswa harus melakukan praktik secara aktif. Dampak hal tersebut adalah kurangnya keterampilan teknis yang dimiliki oleh lulusan program studi, bahkan cenderung tidak menguasai praktik aplikatif teknik elektronika.

Oleh karena itu, perlu dikembangkan media pembelajaran sensor transduser dan instrumentasi industri yang dapat meningkatkan kemampuan teori maupun praktik mahasiswa. Penelitian ini akan mengembangkan sebuah 
multi-sensors yang dapat membantu proses pembelajaran mata kuliah sensor transduser dan instrumentasi industri yang meliputi teori dan praktikum tentang komponen sensor, komponen tranduser, aktuator, kontroler dan berbagai rangkaian aplikasi sistem kendali. Trainer multi-sensors yang akan dikembangkan merupakan gabungan dari trainer komponen sensor transduser dan aplikasi rangkaian sistem instrumentasi industri. Manfaat penelitian ini adalah menghasilkan trainer instrumentasi industri sebagai alat bantu pembelajaran teori dan praktikum mahasiswa. Target dan inovasi yang diharapkan dari hasil riset ini adalah pengembangan media pembelajaran baru berupa trainer aplikasi multi-sensors yang dapat dimanfaatkan oleh mahasiswa Prodi PTE FT UNJ. Temuan penelitian ini dapat dimanfaatkan oleh peneliti lain atau institusi pendidikan lain yang memerlukan media pembelajaran teori dan praktikum sensor transduser dan instrumentasi industri.

\section{METODE}

Penelitian ini dilaksanakan dengan 2 (dua) tahap kegiatan yakni: (i) tahap perancangan dan pengembangan dengan desain penelitian dan pengembangan (research and development/R\&D) yaitu menggunakan model pengembangan media dengan ADDIE (analysis, design, development, implementation and evaluation) (Drljača et al., 2017). Sistem pembelajaran yang mencakup di dalamnya berkaitan dengan pengolahan dan pemilihan konten (sumber belajar), penyusunan strategi pembelajaran, dan juga mencakup pemilihan dan pengembangan media yang akan digunakan, dan evaluasi ketercapaian tujuan (Branch, 2010); dan (ii) tahap implementasi yang dilakukan untuk menilai penggunaan Trainer Aplikasi Multi-Sensors (TAMS).

Terdapat lima tahapan pada model ADDIE dalam membuat model pengembangan sistem, yakni:

1) Tahap analisis (analysis), yang mencakup (i) analisis isi, yakni melakukan penyesuaian isi materi yang akan dimuat dalam media pembelajaran Multi-Sensors dalam konteks pembelajaran yang mengarahkan mahasiswa untuk lebih aktif (student center); dan (ii) analisis kebutuhan mahasiswa, yakni menganalisis media yang benarbenar dibutuhkan mahasiswa.

2) Tahap desain (design), yang mencakup (i) perancangan desain produk, yakni merancang desain trainer pembelajaran sesuai materi sensor tranduser dan instrumentasi industri; (ii) penyusunan materi, yakni isi di dalam media pembelajaran adalah materi sensor tranduser dan instrumentasi industri; dan (iii) menyusun instrumen penilaian produk, yakni membuat instrumen penilaian trainer berupa angket yang ditujukan untuk ahli materi (dosen mata kuliah), ahli media, dan mahasiswa sebagai sasaran implementasi trainer.

3) Tahap pengembangan (development), yang mencakup (i) pembuatan produk, yakni semua komponen yang telah dipersiapkan pada tahap desain dirangkai menjadi satu kesatuan bentuk trainer yang utuh; (ii) validasi, yakni produk awal (trainer) divalidasi oleh ahli materi dan ahli media. Hasil validasi berupa komentar, saran, dan masukan yang dijadikan sebagai dasar untuk melakukan revisi terhadap trainer yang dikembangkan; dan (iii) revisi, yakni produk direvisi berdasarkan komentar, saran, dan masukan dari ahli materi dan ahli media.

4) Tahap implementasi (implementation), berupa uji coba kelompok kecil mahasiswa untuk penggunaan Trainer Aplikasi Multi-Sensor. Pada tahap ini juga dibagikan angket untuk mengetahui penilaian mahasiswa mengenai trainer yang dikembangkan.

5) Tahap evaluasi (evaluation), yakni melakukan evaluasi untuk mengukur ketercapaian tujuan pengembangan produk trainer aplikasi multi-sensor. Evaluasi ini digunakan untuk mengetahui keefektifan pengembangan trainer. Oleh karena masa pandemi Covid-19 yang tidak memungkinkan adanya kegiatan pembelajaran praktikum secara tatap muka (off-line), maka kegiatan evaluasi produk tidak dilakukan pada penelitian.

\section{HASIL DAN PEMBAHASAN}

Dalam penelitian ini, tahap analisis (analysis) dilakukan untuk mendapatkan analisis kebutuhan pengguna (mahasiswa) terhadap trainer aplikasi Multi-Sensors (TAMS). Pengumpulan data dilakukan survey online kepada mahasiswa Program Studi Pendidikan Teknik Elektronika FT-UNJ dan mendapat respon sebanyak 56 (lima puluh enam) mahasiswa. Dari hasil survey tersebut terlihat bahwa selama ini praktikum Mata Kuliah Sensor dan Instrumentasi belum didukung dengan keberadaan dan pemanfaatan modul serta media praktikum secara maksimal sehingga seluruh responden menyatakan perlu untuk dibuat trainer baru untuk mendukung mata kuliah tersebut dan mayoritas responden setuju jika trainer praktikum sensor dan instrumentasi menjadi satu.

Hasil survey juga menunjukkan beberapa hal yang diharapkan ada pada trainer baru yang akan dibuat (i) kebutuhan perangkat/komponen imput yakni sensor suhu, sensor cahaya, RFID, sensor getar, sensor gas, sensor warna, sensor logam, sensor jarak, sensor berat, PIR, sensor ultrasonic, sensor kelembapan tanah, sensor suara, sensor api, sensor alkohol, sensor keseimbangan, dan sensor yang digunakan di industri secara umum; (ii) kebutuhan perangkat/komponen proses yakni mikrokontroler dan mikroprosesor (Arduino uno/mega, ESP32/8266, Wemos D1, mikrokontroller atmega 32, atmega 8535, Raspberry Pi); (iii) kebutuhan 
perangkat/komponen output yakni LCD, lampu, relay, buzzer, piston, motor servo, driver relay, motor DC, buzzer, driver transistor, LED 8 buah; dan (iv) kebutuhan perangkat/komponen lainnya, yakni modul komunikasi, bluetooth, wi-fi atau yang tipe wires seperti port serial/ ethernet card, interface, kabel yang memudahkan saat merangkai projek, tampilan pada monitor bisa menggunakan layar sentuh, modul praktikum yang bisa dilihat dengan mudah.

Gambar 1 menjelaskan tahap desain (design) pembuatan trainer TAMS yang meliputi penyusunan materi, perancangan desain produk, dan penyusunan instrumen penilaian.

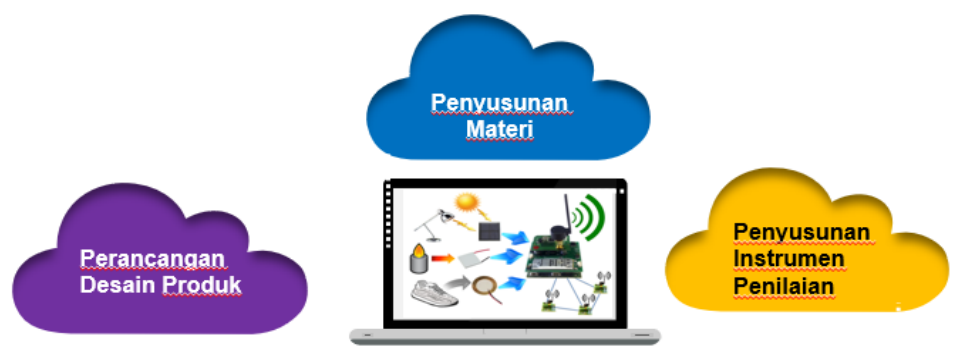

Gambar 1. Desain pembuatan trainer TAMS

Penyusunan materi mengacu pada kurikulum Prodi Pendidikan Teknik Elektronika untuk mata kuliah Sensor Transduser dan Instrumentasi Industri. Adapun materi yang ada pada 2 (dua) mata kuliah tersebut berdasarkan Rencana Pembelajaran Semester (RPS) sebagai berikut: (a) materi mata kuliah sensor transduser: pengertian sensor dan transduser; sifat, klasifikasi dan karakteristik sensor dan transduser; sistem akuisisi data pada sensor dan transduser; jenis dan fungsi sensor dan transduser; dan aplikasi sensor dan tranduser di industri; dan (b) materi mata kuliah instrumentasi industri: konsep dasar sistem instrumentasi; fungsi komponen sistem instrumentasi; karakteristik input-output sensor dan transduser; teknologi instrumentasi dan pengendalian di industri; metode pengukuran dalam sistem instrumentasi industri; metode pengukuran dalam sistem instrumentasi pada berbagai besaran seperti tekanan, berat, aliran, suhu, radiasi, kimiawi, dsb; sistem instrumentasi industri berbasis IoT; dan sistem otomasi pada industri.

Pada tahap perancangan awal desain produk, dirancang desain produk TAMS sebagai berikut (Gambar 2):

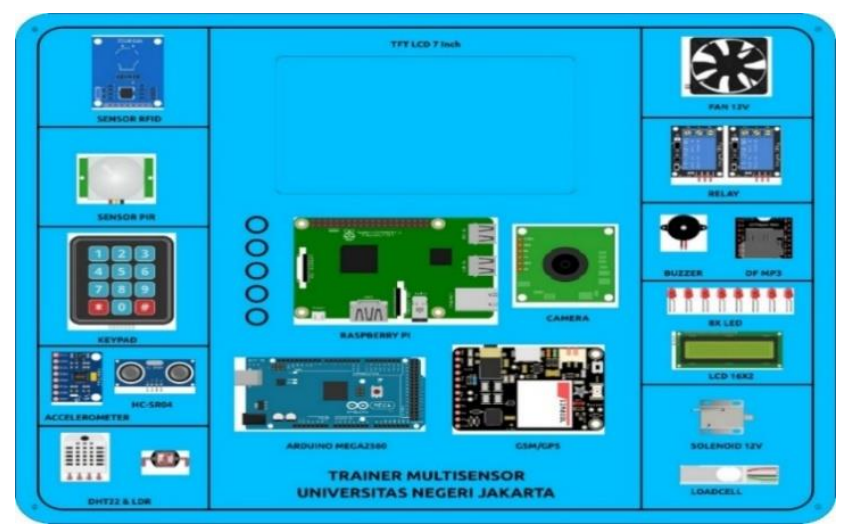

Gambar 2. Rancangan awal trainer TAMS

Trainer ini didesain dengan 4 (empat) layer seperti pada Tabel 1-4 untuk memudahkan sekaligus membedakan bentuk komponen/rangkaian yang akan disusun pada trainer.

Tabel 1. Desain trainer-layer 1

\begin{tabular}{lll}
\hline Input & Proses & Output \\
\hline PIR & Arduino & Solenoid \\
\hline Ultrasonic & Arduino & LCD \\
\hline Keypad & Arduino & Solenoid \\
\hline DHT22 & Arduino & Fan (motor DC) \\
\hline RFID & Arduino & Speaker \\
\hline Akselerometer & Arduino & Speaker \\
\hline Kamera & Arduino & Speaker \\
\hline
\end{tabular}




\begin{tabular}{lll}
\hline LDR & \multicolumn{1}{c}{ Arduino } & LED \\
\hline & Tabel 2. Desain trainer-layer 2 \\
\hline Input & Proses & Output \\
\hline PIR, Ultrasonc & Arduino & Solenoid \\
\hline RFID, Keypad & Arduino & Solenoid, Speaker \\
\hline PIR, Akselerometer & Arduino & LED, Speaker \\
\hline DHT22, Ultrasonic & Arduino & LCD, Speaker \\
\hline LDR, Ultrasonic & Arduino & LCD, Speaker \\
\hline Kamera, PIR & Arduino & LED, Speaker, LCD \\
\hline
\end{tabular}

Tabel 3. Desain trainer-layer 3

\begin{tabular}{lll}
\hline Input & Proses & Output \\
\hline PIR, Ultrasonic, & Raspberry & LED, Speaker \\
Akselerometer & & \\
\hline RFID, Keypad, PIR & Arduino & Speaker, Solenoid \\
\hline
\end{tabular}

Tabel 4. Desain trainer-layer 4

\begin{tabular}{lll}
\hline \multicolumn{1}{c}{ Input } & \multicolumn{1}{c}{ Proses } & \multicolumn{1}{c}{ Output } \\
\hline PIR, Kamera & Raspberry & LED \\
\hline GPS, RFID & Raspberry & Solenoid \\
\hline RFID, Load Cell & Raspberry & LCD \\
\hline
\end{tabular}

Pada tahap penyusunan penilaian, instrumen penelitian dibuat untuk memperoleh penilaian dari ahli media, ahli materi dan pengguna (mahasiswa) terkait sejauh mana trainer TAMS berfungsi dan dapat digunakan. Adapun kisi-kisi instrumennya seperti pada Tabel 5-7 di bawah ini:

Tabel 5. Kisi-kisi instrumen validasi ahli media

\begin{tabular}{|c|c|}
\hline Aspek & Indikator \\
\hline \multirow[t]{3}{*}{ Umum } & $\begin{array}{l}\text { Kreatif dan inovatif (baru, luwes, menarik, cerdas, unik, } \\
\text { dan tidak asal beda) }\end{array}$ \\
\hline & $\begin{array}{l}\text { Komunikatif (mudah dipahami serta menggunakan } \\
\text { bahasa yang baik, benar, dan efektif) }\end{array}$ \\
\hline & $\begin{array}{l}\text { Unggul (memiliki kelebihan dibanding media } \\
\text { pembelajaran lain) }\end{array}$ \\
\hline \multirow[t]{9}{*}{$\begin{array}{l}\text { Aspek Instalasi } \\
\text { Perangkat Lunak }\end{array}$} & $\begin{array}{l}\text { Efektif dan efisien dalam pengembangan maupun } \\
\text { penggunaan media pembelajaran }\end{array}$ \\
\hline & Reliabilitas (kehandalan) \\
\hline & $\begin{array}{l}\text { Maintainable (dapat dipelihara atau dikelola dengan } \\
\text { mudah) }\end{array}$ \\
\hline & $\begin{array}{l}\text { Usabilitas (mudah digunakan dan sederhana dalam } \\
\text { pengoperasian) }\end{array}$ \\
\hline & $\begin{array}{l}\text { Ketepatan pemilihan jenis aplikasi/software/tool untuk } \\
\text { pengembangan }\end{array}$ \\
\hline & $\begin{array}{l}\text { Kompatibilitas (media pembelajaran dapat diinstalasi } \\
\text { dan dijalankan di berbagai hardware dan software yang ada) }\end{array}$ \\
\hline & $\begin{array}{l}\text { Pemaketan program media pembelajaran secara terpadu } \\
\text { dan mudah dalam eksekusi }\end{array}$ \\
\hline & $\begin{array}{l}\text { Dokumentasi multimedia pembelajaran yang lengkap } \\
\text { meliputi : petunjuk instalasi (jelas, singkat, dan lengkap), } \\
\text { penggunaan, troubleshooting (jelas, terstruktur, dan } \\
\text { antisipatif), desain program (jelas, dan menggambarkan } \\
\text { alur kerja program) }\end{array}$ \\
\hline & $\begin{array}{l}\text { Reusabilitas (sebagian atau seluruh media pembelajaran } \\
\text { dapat dimanfaatkan kembali untuk mengembangkan } \\
\text { media lain). }\end{array}$ \\
\hline $\begin{array}{l}\text { Aspek Komunikasi } \\
\text { Visual }\end{array}$ & $\begin{array}{l}\text { Komunikatif: unsur tampilan mendukung materi ajar, } \\
\text { agar mudah dicerna }\end{array}$ \\
\hline
\end{tabular}




\begin{tabular}{ll}
\hline Aspek & Indikator \\
\hline & Sederhana : visualisasi tidak rumit, agar tidak mengurangi \\
kejelasan isi materi ajar dan mudah diingat \\
\cline { 2 - 2 } Tata letak (layout): peletakan dan susunan unsur-unsur \\
visual terkendali dengan baik, agar memperjelas peran \\
dan hierarki masing-masing unsur tersebut \\
$\begin{array}{l}\text { Navigasi yang familiar dan konsisten agar efektif dalam } \\
\text { penggunaannya }\end{array}$ \\
\hline
\end{tabular}

Tabel 6. Kisi-kisi instrumen validasi ahli materi

\begin{tabular}{ll}
\hline Aspek & Indikator \\
\hline Pembelajaran & Kejelasan tujuan pembelajaran \\
\hline Relevansi tujuan pembelajaran dengan kurikulum/standar \\
kompetensi/kompetensi dasar
\end{tabular}

Tabel 7. Kisi-kisi instrumen penggunaan trainer

\begin{tabular}{|c|c|}
\hline Aspek & Indikator \\
\hline \multirow[t]{12}{*}{ Aspek Penggunaan } & Trainer TAMS mudah digunakan tanpa kesulitan \\
\hline & Respon Trainer TAMS mudah dipahami \\
\hline & $\begin{array}{l}\text { Trainer TAMS merespon segala yang diperintahkan } \\
\text { pengguna }\end{array}$ \\
\hline & Trainer TAMS menambah semangat belajar \\
\hline & Trainer TAMS memberikan suasana baru dalam belajar \\
\hline & Trainer TAMS menambah pengetahuan \\
\hline & $\begin{array}{l}\text { Trainer TAMS sesuai dengan bahan mata kuliah Sensor } \\
\text { dan Instrumentasi }\end{array}$ \\
\hline & Tampilan Trainer TAMS menarik \\
\hline & Perpaduan warna Trainer TAMS sesuai \\
\hline & $\begin{array}{l}\text { Jenis huruf yang digunakan dalam Trainer TAMS terbaca } \\
\text { dengan jelas }\end{array}$ \\
\hline & Tampilan menu-menu Trainer TAMS menarik \\
\hline & Tombol navigasi Trainer TAMS mudah dipahami \\
\hline
\end{tabular}

Pada tahap pengembangan (development) dilakukan pembuatan produk, validasi dan revisi. Pembuatan produk trainer aplikasi multi-sensors (TAMS) ini meliputi pembuatan perangkat keras (bardware) dan perangkat lunak (software). Trainer ini memiliki berbagai sensor, output serta modul pengendali berupa Arduino Mega2560 dan didukung oleh Raspberry Pi. Trainer ini juga dilengkapi dengan LCD touchscreen dan Raspberry pada blokA trainer, sedangkan blok-B trainer merupakan kumpulan berbagai sensor dan didukung oleh kontroler Arduino. 
Secara lebih rinci, blok-A (bagian atas trainer) terdiri dari modul GPS, modul kamera, LCD 16x2, buzzer, speaker, 8xLED, monitor LCD touchscreen 7 inch's dan Raspberry Pi board. Adapun blok-B (bagian bawah trainer) terdiri dari berbagai modul sensor (LDR, ultrasonic, RFID/NFC V3, accelerometer, suhu dan kelembapan/DHT22, PIR, loadcell), modul output (mp3, relay, solenoid, fan/motor DC), keypad, modul nodemcu ESP8256 dan dan Arduino Mega2560 board. Gambar 3-4 menunjukkan bentuk produk trainer TAMS dengan spesifikasi teknis fisik trainer sebagai berikut: (i) dimensi luar trainer/box (p x l x t) $45 \mathrm{~cm}$ x $33 \mathrm{~cm}$ x 15 $\mathrm{cm}$; (ii) dimensi dalam trainer ( $\mathrm{p} \times \mathrm{l}$ ) $43 \mathrm{~cm} \times 31 \mathrm{~cm}$; dan (iii) berat trainer $5 \mathrm{~kg}$.

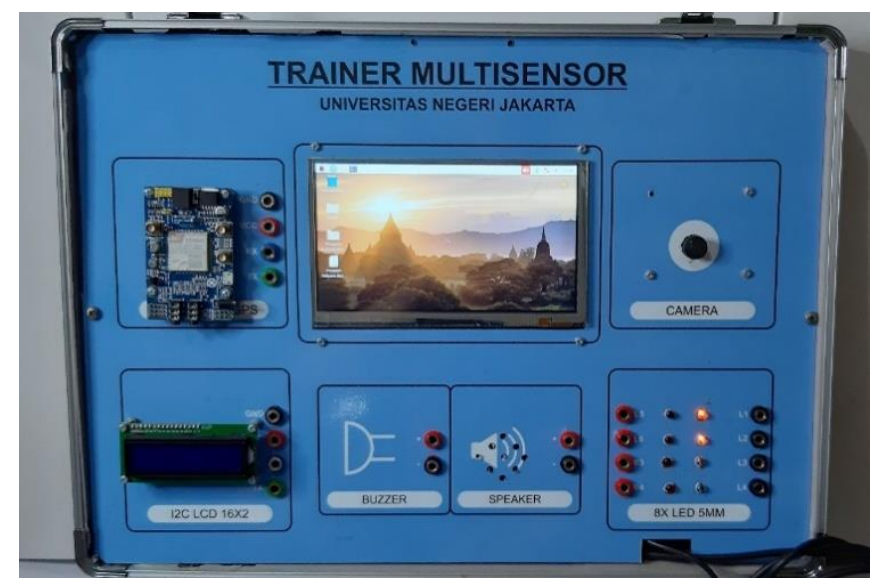

Gambar 3. Tampilan blok A-trainer TAMS

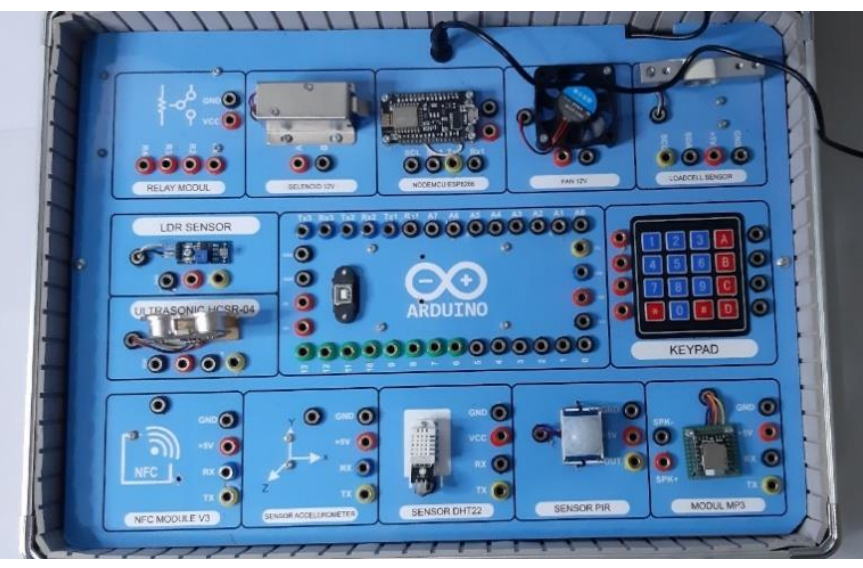

Gambar 4. Tampilan blok B-trainer TAMS

Gambar 5-6 berikut merupakan contoh wiring rangkaian/modul pada layer-1 dan layer-2 yang sesungguhnya merupakan kombinasi rangkaian input sensor, kontroler dan output yang dibuat pada trainer TAMS.

\section{Layer-1}

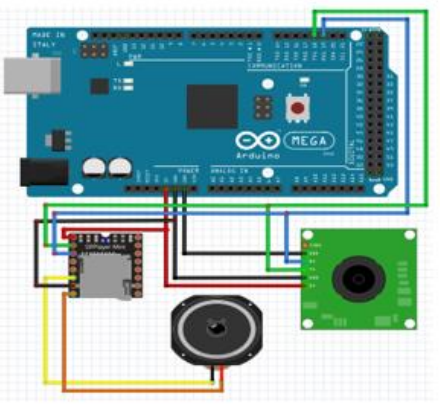

Kamera dan Speaker

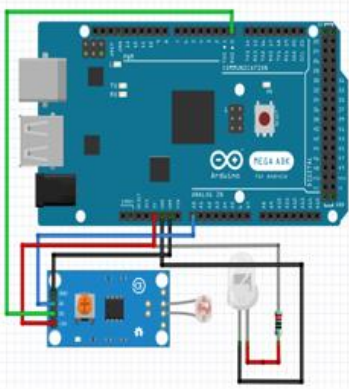

Sensor LDR dan LED

Gambar 5. Contoh wiring rangkaian/modul pada layer 1 


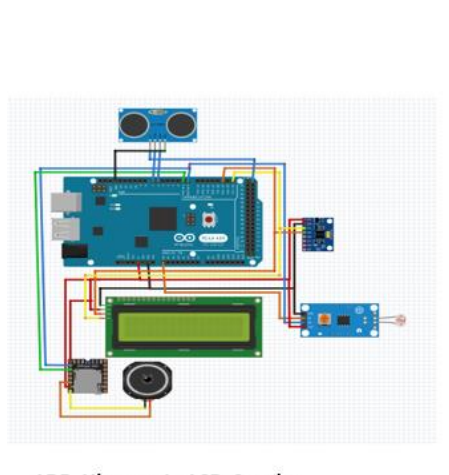

LDR, Ultrasomic, LCD, Speaker
Layer-2

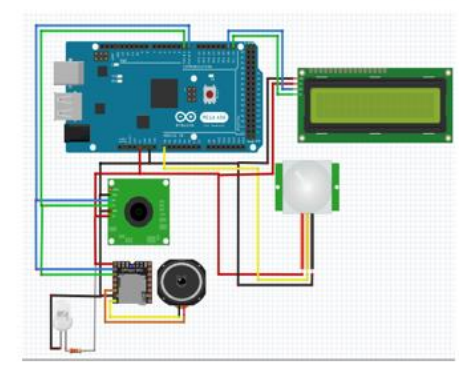

Kamera, PIR, LED, LCD, Speaker

Gambar 6. Contoh wiring rangkaian/modul pada layer 2

Secara paralel pada saat pembuatan perangkat keras trainer, maka disusun modul praktikum yang berisi 15 (lima belas) judul percobaan/praktikum yang akan digunakan pada trainer TAMS. Modul praktikum itu diujicobakan satu persatu pada trainer untuk mengetahui kebenaran rangkaian yang ada sekaligus program (source code) yang digunakan pada modul praktikum. Modul praktikum ini disusun untuk mendukung berbagai percobaan yang ada di trainer TAMS. Modul ini disusun secara sistematis agar memudahkan mahasiswa dalam melaksanakan tahapan praktikum, dengan sistematika setiap judul praktikumnya meliputi; 1) tujuan praktikum;2) kerangka teori; 3) komponen dan alat; 4) konfigurasi penggunaan pin; 5) skema rangkaian; 6) petunjuk percobaan; 7) pertanyaan; dan 8) program percobaan (source code). Tabel 8 di bawah ini menunjukkan daftar 15 judul praktikum yang dapat dilakukan pada trainer TAMS.

Tabel 8. Judul-judul praktikum menggunakan trainer TAMS

\begin{tabular}{cl}
\hline No. & Judul Praktikum \\
\hline 1 & Sensor PIR dan Output Solenoid \\
\hline 2 & Sensor Ultrasonic dan Output LCD 16x2 \\
\hline 3 & Input Keypad dan Output Solenoid \\
\hline 4 & Sensor Suhu DHT22 dan Output Motor DC (Fan) \\
\hline 5 & Sensor RFID dan Output Speaker \\
\hline 6 & Sensor Akselerometer GY521 dan Output Speaker \\
\hline 7 & Sensor LDR dan Ouput LED \\
\hline 8 & Sensor PIR, Sensor Ultrasonic, dan Output Solenoid \\
\hline 10 & Sensor RFID \& Keypad, dan Output Solenoid \& Speaker \\
\hline 11 & Sensor Akselerometer GY521\& PIR, dan Output Speaker \& LED \\
\hline 12 & Sensor Ultrasonic \& DHT22 dan Output LCD 16x2 \& Speaker \\
\hline 13 & Sensor Load Cell \& PIR dan Output Speaker \& LED \\
\hline 14 & Sensor RFID, Keypad \& PIR, dan Output Solenoid \& Speaker \\
\hline 15 & Input Keypad \& LED, dan Output Speaker \\
\hline
\end{tabular}

Tahap validasi pada penelitian ini dilakukan dengan memberikan instrumen penilaian kepada ahli materi dan ahli media yang relevan dengan topik penelitian. Ahli materi pada penelitian ini terdiri dari 2 (dua) orang yaitu dosen mata kuliah sensor dan instrumentasi industri dari FT UNJ. Hasil uji validitas oleh ahli materi memperoleh persentase rata-rata skor penilaian sebesar $85,25 \%$ yang berarti valid dan sangat layak digunakan. Ahli media pada penelitian ini terdiri dari 2 orang dosen ahli teknologi pendidikan (media pembelajaran). Hasil uji validitas oleh ahli media memperoleh persentase rata-rata skor penilaian sebesar 78,04\% yang berarti valid dan layak digunakan. Selanjutnya berdasarkan masukan dari dari ahli materi dan ahli media, dilakukanlah revisi minor produk trainer TAMS. Revisi ini tidak mengubah desain dari trainer, namun dilakukan dengan memberikan penambahan beberapa fungsi trainer, perapihan pada panduan penggunaan trainer dan modul praktikum.

Selanjutnya di tahap implementasi (implementation), dibagikan angket untuk mengetahui penilaian mahasiswa mengenai trainer yang dikembangkan. Dikarenakan kondisi pandemic Covid-19 yang tidak memungkinkan mengumpulkan mahasiswa dalam jumlah banyak, maka trainer ini diujicobakan secara singkat kepada 5 (lima) orang mahasiswa yang dipilih secara acak. Tahap ini dilakukan untuk menilai sejauh mana usabilitas penggunaan trainer TAMS di tangan pengguna (mahasiswa). Hasil penilaian mahasiswa terhadap 
penggunaan trainer sebesar 90\% sehingga dapat disimpulkan bahwa trainer TAMS sangat layak digunakan. Secara kualitatif mahasiswa pengguna menilai bahwa trainer TAMS dapat berfungsi dengan baik dan mudah untuk digunakan.

\section{PENUTUP}

Penelitian ini telah berhasil merancang dan mengembangkan trainer aplikasi multi-sensors (TAMS). Trainer ini memiliki berbagai sensor, output serta modul pengendali berupa Arduino Mega2560 dan didukung oleh Raspberry Pi. Secara lebih rinci, blok-A (bagian atas trainer) terdiri dari modul GPS, modul kamera, LCD 16x2, buzzer, speaker, 8xLED, monitor LCD touchscreen 7 inch's dan Raspberry Pi board. Adapun blok-B (bagian bawah trainer) terdiri dari berbagai modul sensor (LDR, ultrasonic, RFID/NFC V3, accelerometer, suhu dan kelembapan/DHT22, PIR, loadcell), modul output (mp3, relay, solenoid, fan/motor DC), keypad, modul nodemcu ESP8256 dan dan Arduino Mega2560 board.

Trainer ini dilengkapi dengan modul praktikum yang berisi 15 (lima belas) judul percobaan/praktikum yang akan digunakan pada trainer TAMS. Modul praktikum ini disusun secara sistematis agar memudahkan mahasiswa dalam melaksanakan berbagai praktikum menggunakan trainer TAMS. Sistematika modul praktikumnya terdiri dari a) tujuan praktikum; b) kerangka teori; c) komponen dan alat; d) konfigurasi penggunaan pin; e) skema rangkaian; f) petunjuk percobaan; g) pertanyaan; dan h) program percobaan (source code).

Hasil uji validitas oleh ahli materi memperoleh persentase rata-rata skor penilaian sebesar $85,25 \%$ yang berarti valid dan sangat layak digunakan. Hasil uji validitas oleh ahli media memperoleh persentase rata-rata skor penilaian sebesar 78,04\% yang berarti valid dan sangat layak digunakan. Hasil penilaian mahasiswa terhadap penggunaan trainer sebesar 90\% sehingga dapat disimpulkan bahwa trainer TAMS sangat layak digunakan. Secara kualitatif mahasiswa pengguna menilai bahwa trainer TAMS dapat berfungsi dengan baik dan mudah untuk digunakan.

\section{REFERENSI}

Ajao, L. A., Agajo, J., \& Oke, A. O. A. J. T. (2017). Development of a Low-Cost Digital Logic Training Module for Students Laboratory Experiments. Journal of Engineering and Technology, 8(1), 30-44.

Branch, R. M. (2010). Instructional Design: The ADDIE Approach Utilizes a simple, yet robust organizing framework. Uses a thematic approach to the content Presents the concept, theory and practice for ADDIE Contains a glossary. Springer.

Drljača, D., Latinović, B., Stanković, Ž., \& Cvetković, D. (2017). ADDIE Model for Development of E-Courses. 242247. https://doi.org/10.15308/sinteza-2017-242-247

Dunn, T. J., \& Kennedy, M. (2019). Technology Enhanced Learning in higher education; motivations, engagement and academic achievement. Computers \& Education. https://doi.org/10.1016/J.COMPEDU.2019.04.004

Elfizon, Muskhir, M., \& Candra, O. (2017). Pengembangan Media Trainer Elektronika dalam Pembelajaran Teknik Elektronika pada Pendidikan Vokasi Teknik Elektro FT UNP. Seminar Nasional Vokasi Dan Teknologi (SEMNASVOKTEK), 153-160.

Hacker, C. (2009). A Low Cost Student Constructed Digital Trainer. Proceedings of the 2009 AaeE Conference, 1-7.

Kayimbaşioğlu, D., Oktekin, B., \& Haci, H. (2016). Integration of Gamification Technology in Education. Procedia Computer Science, 102(August), 668-676. https://doi.org/10.1016/j.procs.2016.09.460

Lai, J. W. M., \& Bower, M. (2019). How is the use of technology in education evaluated? A systematic review. Computers and Education, 133, 27-42. https://doi.org/10.1016/j.compedu.2019.01.010

Sahat Siagian. (2014). Development of Basic Electronic Instructional Module and Trainer. European Journal of Computer Science and Information Technology, 2(3), 36-46.

U.S. Departement of Education. (2019). Use of Technology in Teaching and Learning | U.S. Department of Education.

Yusro, M. (2017). Mobile Learning Application for Personal Computer Assembly Techniques as Learning Media in Vocational. $1,9-13$. 